$$
\text { ilmiyat }
$$

Tokat IImiyat Dergisi | Tokat Journal of IImiyat

9/2 (Aralık | December 2021)

ISSN 2717-6134 | e-ISSN 2717-610X

\title{
Hindistan Sûfîlerinden Muhammed Gîsûdırâz’ın Bazı Tasavvufî Görüşleri
}

Certain Sufist Views of Muhammad Gīsūdırāz, an Indian Sūfì

\section{Ömer TAY}

Arş. Gör. Dr., Bingöl Üniversitesi Res. Ass. Dr., Bingöl University

Illahiyat Fakültesi Theology Faculty

Tasavvuf Anabilim Dalı Department of Sufism

Bingöl|Türkiye Bingöl|Turkey

o.tay21@hotmail.com orcid.org/0000-0002-1692-9143

\section{Makale Bilgisi | Article Information}

Makale Türü | Araştırma Makalesi Article Types | Research Article Geliş Tarihi | 22 Eylül 2021 Received | 22 September 2021

Kabul Tarihi | 22 Aralık 2021 Accepted | 22 December 2021

Yayın Tarihi | 30 Aralık 2021 Published | 30 December 2021

\section{Atıf | Cite as:}

Tay, Ömer. “Hindistan Sûfilerinden Muhammed Gîsûdırâz'ın Bazı Tasavvufî Görüşleri [Certain Sufist Views of Muhammad Gīsūdırāz, an Indian Sūfi]". Tokat Illmiyat Dergisi | Tokat Journal of Ilmiyat 9/2 (Aralık | December 2021), 631-653. https://doi.org/10.51450/ilmiyat.999145

\section{intihal | Plagiarism:}

Bu makale, iTenticate aracılığıyla taranmış ve intihal içermediği teyit edilmiştir. | This article, has been scanned by iThenticate and no plagiarism has been detected.

\section{Copyright $\odot$}

Published by Tokat Gaziosmanpaşa University Faculty of Islamic Sciences. Tokat | Turkey. https://dergipark.org.tr/ilmiyat

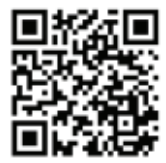




\section{Certain Sufist Views of Muhammad Gīsūdırāz, an Indian Sūfĩ}

Abstract: A significant part of India was invaded by the Muslims during the Ghaznavid period. However, the Süfis contributed significantly to the popularity of Islam and access of the masses to Islam. So much so that until the beginning of the twentieth century, it was generally accepted in the India that the path to the advances and blessings of Islam was through tariqa training. Although there were different sects in India, the Chishti order spread further than the other sects due to its temperament suited to the region. As a matter of fact, the fact that these individuals emphasized the values of tolerance and brotherhood of Islam against the caste system in India and the belief of tawhid against the multi-religious system were effective in the conversion of the local people to Islam. The present study was conducted on Gisūdırāz (d. 825/1422), one of the Indian Süfìs who developed a unique methodology within the Chishtī order and his Sūfi views on theoretical principles such as the connection between the sharia-tariqa, prophethood-guardianship, and on the Süfĩ customs such as allegiance, disciples, and khalīfate. Gīsūdırāz, an Indian Sūfî, joined Çırâğ-1 Dehlī (d. 757/1356), another leading Chishtī sheikh of the time, when he was about fifteen or sixteen, and received the caliphate from him at the age of thirty. Gīsūdırāz, who served him for twenty-one years, was accepted as one of the leading caliphs of Çırâğ-ı Dehlī. Gīsūdırāz, a versatile scholar, wrote several books especially on Qur'an, hadith, fiqh and Süfīsm. He also learned several languages, notably Arabic, Persian, Sanskrit and Hindi. The present article aims to introduce certain mystical views of Gīsūdırāz, who was on the lines of the Ahl as-sunnah. Gīsūdırāz 's Sūfĩ views were employed as a method, the books written by Gīsūdırāz and the original works written about him in the following centuries were accepted as the foundation of the study. Gīsūdırāz, who considered learning external sciences compulsory for the devotee, considered that Süfism is a serious field of science, therefore a requirement for those who want to study science and prevent insanity or infidelity. The position of Süfism in Islamic sciences, its relationship with sharia and where it will be placed within the circle of Islam have been discussed since the early times when Sūfīsm began to emerge among Islamic sciences. From time to time, sharia and tarīqa are compared and it is realized that they are discussed as to whether they are the same or different things. Gīsūdırāz, who considered the sharia and the tariqa as the same Süfi concept, argued that sharia refers to the words of the perfect individual and the tariqa refers to the actions of the perfect individual, and the sharia and tariqa are the same thing, one represents the theoretical aspect of Islam and the other the practical aspect, and that it is unnecessary to consider them different. The subject of prophecy and guardianship, which was introduced to the Sūfî literature during the early period, also interested Gīsūdırāz. Although certain sectarian Sūfīs claimed that wilāyah is superior to prophecy, he argued based on verses that prophecy is superior to wilayyah and the last degree of wilāyah is the first degree of prophecy. Nothing is more effective on the soul of human beings than conversation, be it good or bad. Thus, Gīsūdırāz argued that for the divine love of the servant, an individual should participate in the conversation of the lovers since the devotee would experience a rapid change as the lovers constantly utter words of love. Gīsūdırāz refuted Mu'tazila by arguing that miracles are true and ignoring the miracles entails the denial of Allah's attribute of might. Gīsūdırāz stated that the soul is one, not several, but it has different states and levels, namely emmāre, levvāme and mutmainne. Gīsūdırāz, who defended the idea that the self is evil except that of the prophets, argued that it could be transformed into the level of levvāme with struggle, rigor and self-purification, and then could rise to the level of mutmainne.

Keywords: Sufism, India, Chishti order, Gīsūdırāz, wilāyah. 


\section{Hindistan Sûfîlerinden Muhammed Gîsûdırâz’nn Bazı Tasavvufî Görüşleri}

Öz: Hindistan'ın önemli kısmı Gazneliler döneminde Müslümanların eline geçmiștir. Fakat orada İslâm'ın tutunması ve daha geniş kitlelere ulaştırılmasında sûfilerin önemli derecede katkıları olmuştur. Öyle ki yirminci yüzyılın başına kadar Hindistan coğrafyasında İslâm'in feyz ve bereketinden istifade edebilmenin yolunun tarîkat terbiyesinden geçmek olduğu genel kabul gören bir husus olmuştur. Hindistan'da farklı tarîkatlar bulunmakla birlikte o bölgeye hâs mizacıyla Çiştiyye tarîkatı diğer tarîkatlardan daha fazla yayılma şansı bulmuştur. Nitekim bu zatların Hindistan'daki kast sistemine karşı İslâm'ın müsamaha ve kardeşlik değerlerini, çok dinli sisteme karşı da tevhîd inancını ön plana çıkarmaları yerli halkın Müslüman olmalarında etkili olmuştur. Çalışmada, Hindistan sûfîlerinden ve Çiştiyye tarîkatı içerisinde kendine hâs bir metodu olan Gîsûdırâz’’n (öl. 825/1422) tasavvufun nazarî esasları arasında sayılan şerîat-tarîkat bağlantısı, nübüvvet-velâyet ile tasavvufun âdâbve erkânı kabul edilen bîat, mürîd, hilâfet gibi bazı tasavvufî görüşleri konu edinilmiştir. Hindistan sûfîlerinden olan Gîsûdırâz, on beş on altı yaşlarında dönemin önde gelen Çiştiyye meşâyihinden Çırâğ-1 Dehlîye (öl. 757/1356) intisab etmiş, otuz yaşında ondan hilâfet icazetini almıştır. Yirmi bir yıl onun hizmetinde bulunan Gîsûdırâz, Çırâğ-1 Dehlînnin önde gelen halifeleri arasında kabul edilmiştir. Çok yönlü bir âlim olan Gîsûdırâz, özellikle Kur'ân, hadis, fikıh ve tasavvuf alanlarında birçok eser kaleme almıştır. Ayrıca başta Arapça, Farsça, Sanskritçe ve Hintçe olmak üzere çeşitli dilleri öğrenmiştir. Bu makale, Ehl-i sünnet çizgisinde olan Gîsûdırâz'ın bazı tasavvufî görüşlerini gün yüzüne çıkarmayı amaçlamıştır. Yöntem olarak Gîsûdırâz'ın tasavvufî görüşleri ortaya konulurken literatür açısından Gîsûdırâz' in kaleme aldığ kitaplar ve onu takip eden asırlarda onunla ilgili kaleme alınan muahhar eserler esas kabul edilmiştir. Sâlik için zâhirî ilimlerin tahsilini zorunlu gören Gîsûdırâz, tasavvufun ciddi bir alan olduğunu bu yüzden bu yola girmek isteyenlerin deli veya kafir olma tehlikesine düşmemek için ilim tahsil etmelerini zorunlu görmüştür. Tasavvufun İslâmî ilimler içerisindeki konumu, şeriat ile olan münasebeti ve İslâm dairesi içerisinde nereye yerleştirileceği hususu tasavvufun İslâmî ilimler arasında tebarüz etmeye başladığı ilk zamanlardan günümüze kadar tartışılmıştır. Zaman zaman şeriat ve tarîkat karşılaştırılması yapılıp bunların aynı mı yoksa farklı şeyler mi diye tartışıldığı görülür. Şerîat ve tarîkatı ayrı şeyler değil de birer tasavvufî kavram olarak ele alan Gîsûdırâz, şerîatın, kâmil insanın sözlerine, tarîkatın ise kâmil insanın fiillerine denildiğini yani şerîat ile tarîkatın aynı şey olduğunu, birisinin İslâm'ın nazarî yönünü diğerinin ise amelî yönünü temsil ettiğini ve bunları birbirinden farklıymış gibi göstermenin gereksiz olduğunu ifade etmeye çalışmıştır. Erken dönemden itibaren tasavvuf literatürüne giren nübüvvet-velâyet konusu Gîsûdırâz'ı da ilgilendirmiștir. Ona göre her ne kadar bazı sekr ehli sûfîler velâyetin nübüvvetten üstün olduğunu iddia etmiş olsalar da ayetlerle nübüvvetin velâyetten üstün olduğunu belirtmiş ve velâyetin son derecesinin nübüvvet basamağının ilk derecesi olduğunu ifade etmiştir. İnsanoğlunun nefsine hiçbir şey, hayır olsun şer olsun sohbet kadar müessir değildir. Bu bağlamda Gîsûdırâz, kulda ilâhî aşkın meydana gelebilmesi için kişinin âşıkların sohbetinde bulunması gerektiğini zira âşıkların sürekli aşk ile ilgili sözleri sarf etmelerinden sâlikin üzerinde hızlı bir değişim meydana geleceğini belirtmiştir. Mutezile'ye reddiye mahiyetinde Gîsûdırâz, kerâmetin hak olduğunu, kerâmeti yok saymanın Allah'ın kudret sıfatını inkâr etmeyi içerdiğini belirtmiştir. Gîsûdırâz, nefsin birkaç tane değil de bir tane olduğunu fakat farklı hal ve mertebelere sahip olmasından emmâre, levvâme ve mutmainne şeklinde üç mertebesi bulunduğunu belirtmiştir. Peygamberlerin nefsleri hariç nefsin temelinde kötü olduğu fikrini savunan Gîsûdırâz, mücâhede, riyâzat ve nefis tezkiyesi ile levvâme mertebesine dönüştüğünü ardından da mutmainne mertebesine yükseldiğini belirtmiştir.

Anahtar kelimeler: Tasavvuf, Hindistan, Çiştiyye, Gîsûdırâz, Velâyet. 


\section{Giriş}

T ind alt kitasına tasavvufun yerleşmesi bu coğrafyaya İslâm'ın gelmesi kadar eski olup, bu süre hicrî I. milâdî VII. asra kadar uzanır. ${ }^{1}$ Fakat gerçek manada tasavvufun Hind alt kıtasına yerleşmesi, hicrî IV. (m. X.) asrın başında Hallâc'ın (öl. 309/922) Sind'e seferi ile Hücvîrî̀nin (öl. 465/1072) Lahor'a yerleşmesiyle mümkün olduğunu söylemek gerekir. ${ }^{2}$ Hindistan'da Müslümanlar tarafından Delhî Sultanlığı kurulduktan sonra daha önce İslâm coğrafyasında kurulan tarîkat üyeleri irşad ve tebliğ için buralara yerleşerek halkı İslâm’a davet ederler. ${ }^{3}$ Bu bölgede yerli halkın Müslümanlaşmasında etkin rol alanların başında Çiştiyye, Kâdirîyye, Sühreverdîyye ve Nakşibendîyye mürşidleri gelir. ${ }^{4}$ İslâm'a giren yerli halkın büyük bir kısmı, bu sûfîlerin gayretleri sayesinde İslâm'la müşerref olurlar. Fakat şuna da dikkat çekmek gerekir ki Çiştiyye sûfîleri, Hindistan'ın İslâmlaşmasında doğulu ve batılı araştırmacıların ittifakıyla önemli bir paya sahiptirler. Bu zatların Hindistan'daki kast sistemine karşı İslâm'ın müsamaha ve kardeşlik değerlerini, çok dinli sisteme karşı da tevhîd inancını ön plana çıkarmaları yerli halkın Müslüman olmalarında etkili olmuştur. ${ }^{5}$ Bu çalışmada öncelikle Gîsûdırâz'ın kısaca hayatı hakkında bilgi verilmiş daha sonra bazı tasavvufî görüşlerine yer verilmiştir.

\section{Hayatı}

Hindistan'ın önde gelen sûfîlerinden olan Gîsûdırâz'ın ailesi, köken olarak seyyid olup bu aile Afganistan'ın Herât şehrinden Delhi'ye göç etmiştir. Babası Seyyid Yûsuf el-Hüseynî, Çiştiyye mürşidlerinden Nizâmeddin Evliyâ'nın (öl. 725/1325) mürîdidir. ${ }^{6}$ Gîsûdırâz, kesin olmamakla birlikte 720-721/1320-1321 senesinde Delhi'de doğmuştur.7 Tam adı, Seyyid Mu-

1 Alexandre Popovic - Veinstein Gilles, İslâm Dünyasında Tarîkatlar, çev. Osman Türer (İstanbul: Sûfî Yayınları, 2004), 196.

2 Popovic- Gilles, İslâm Dünyasında Tarîkatlar, 199; Hüseyin Çiştî Nizâmî, Sîret-i Tayyibe Hazret-i Muînüddîn-i Çiştî (Lahor: Ekber Beg Yayınları, 2004), 60; Eyyup Akdağ, "Hallâc'1n Mahkeme Süreci ve Katline Fetvâ Verenler”, Dinbilimleri Akademik Araştırma Dergisi 20/2 (2020), 1173.

Popovic- Gilles, İslâm Dünyasında Tarîkatlar, 199.

4 Geniş bilgi için bk. Ömer Tay, Muînüddîn-i Çiştî ve Çiştiyye Tarîkatı (Erzurum: Atatürk Üniversitesi, Sosyal Bilimler Enstitüsü, Doktora Tezi, 2021), 19.

5 Ebu'l Hasan Ali en-Nedvî, İslâm Önderleri Tarihi, çev. Yusuf Karaca (İstanbul: Kayıhan Yayınları, 1992), 3/29; Mevdûdî, Târih-i Çişt u Meşâyih-i Çiştiyye, 165.

6 Abdülhak Muhaddis ed-Dihlevî, Ahbârü'l- Ahyâr fi Esrâri'l-Ebrâr (Tahran: Encümen-i Âsâru Mefâhir-i Ferhengî, 1963), 264; Halik Ahmed Nizâmî, “"Gîsûdırâz', Türkiye Diyanet Vakfi Islâm Ansiklopedisi, (İstanbul: TDV Yayınları, 1996), 14/94; Mürtezâ Kerbelâ-1̂-Hâmid Nâcî, "Seyyid Muhammed Gîsûdırâz'u-Nakdi Nazariye-i Vahdet-i Vücûd-i İbnü'l-Arâbî”, Pejveheşnâme-i Mezâhib-i İslâm 5 (2017), 50.

7 Ebü'l-Feth Sadrüddîn Seyyid Muhammed b. Yûsuf el-Hüseynî Gîsûdırâz, Şerh-i Cevâmi'u'l-Kelim (Lahor: el-Faysal, 2010), 47; Ğulâm Ali Âryâ, Tarîkati Çiştiyye der Hind-u Pakistan (İran: Zevâr 
hammed b. Yûsuf el-Hüseynî ed-Dihlevî (öl. 825/1422)'dir. Sadrüddîn, Hâce Bende Nevâz, Veliyü'l-Ekber ve Gîsûdırâz (uzun saçli) gibi lakaplarla anılmış fakat halk arasında daha çok Gîsûdırâz olarak meşhur olmuştur. ${ }^{8}$ Kaynaklarda bu lakabı almasının nedeni ise şöyle aktarılmıştır: "Bir gün Gîsûdırâz ve bazı arkadaşları mürşidleri Çırâğ-1 Dehlînnin (öl. 757/1356) minderine oturmuşlar. ${ }^{9}$ Şeyhi onları görünce, Gîsûdırâz utancından tanınmamak için uzun saçlarıyla yüzünü kapatmaya çalışmıştır. Onu çok seven şeyhi onu bu şekilde görünce şu beyti okumuştur:

"Her kim Gîsûdırâz' in mürîdi olursa Vallahi hilafyok ona aşk kapısı açılmıştır." diyerek ona olan sevgisini belirtmiş ve bu hadiseden sonra Gîsûdırâz ismiyle meşhur olmuştur. ${ }^{10}$

Diğer Çiştiyye müntesipleri gibi Delhi Sultanı Muhammed b. Tuğluk'un (öl. 752/1351) çeşitli baskılarına mâruz kalan ailesi Devletâbâd'a göç etmek zorunda kalmıştır. O sıralarda beş yaşlarında olan Gîsûdırâz, ilk tahsilini Devletâbâd'ta almış ve on bir yaşında Kur'ân hafızı olmuştur. ${ }^{11}$ Muhammed b. Tuğluk'un ölümünden sonra ailesiyle Delhi'ye dönen Gîsûdırâz, orada dönemin ünlü alimlerden Mevlânâ Tâceddin Bahâdır, Kâdî Abdülmuktedir ve Seyyid Şerefeddin Keyselî'den dinî ilimleri tahsil etmiştir. ${ }^{12}$ Daha sonra Timur'un (öl. 807/1405) saldırılarından dolayı Delhi'den o dönemde Behmenîler'in ${ }^{13}$ hakimiyeti altında olan Gülberge'ye gitmek zorunda kalmıştır. Behmenî sultanı Fîrûz Şah (öl. 790/1388), Gîsûdırâz'ın Delhi'den Dekken'e geldiğini duyunca onu karşılamaya çıkmışır. Ancak sultanın filozoflara ilgi duymasından Gîsûdırâz'ın zamanla ondan uzaklaşmasına yol açmıştır. Fakat Fîrûz Şah'ın halefi ve kardeşi Sultan Şehâbeddin I. Ahmed Şah Behmenî (öl.1422-1436), Gîsûdırâz ile yakın ilgi kurmayı başarmış ve şehrin çıkışında onun için bir yer tahsis etmiştir.

Yayınları, 1964), 181; Ahmed İkbâlüddin, Tezkire-i Hâce Gîsûdırâz (Haydarâbâd, 1966), 29.

8 Şebîr Hüseyin, Sîret-i Pâk Hazret-i Seyyid Muhammed Gîsûdırâz (Lahor: Urdubâzâr, 2002), 10; Kerbelâ-1̂ - Nâcî, "Seyyid Muhammed Gîsûdırâz'u-Nakdi Nazariye-i Vahdet-i Vücûd-i İbnü'lArâbî”, 49-67; İkbâlüddin, Tezkire-i Hâce Gîsûdırâz, 29.

9 Geniş bilgi için bk. Ömer Tay, "Hindistanlı Bir Sûfî: Nasırüddîn Mahmûd b. Yahyâ Çırâğ-1 Dehlî ve Tasavvuf Anlayışı”, Sakarya Üniversitesi İlahiyat Fakültesi Dergisi 23/43 (15 Haziran 2021), 191-215.

10 Ahmed Fârûkî Siyâlvî, Tezkire-i Evliyâ-i Çişt (Lahor: Sadr Bâzâr, ts), 144; Kerbelâ-1̂- Nâcî, "Seyyid Muhammed Gîsûdırâz'u-Nakdi Nazariye-i Vahdet-i Vücûd-i İbnü'l-Arâbî”, 51.

${ }^{11}$ İkbâlüddin, Tezkire-i Hâce Gîsûdırâz, 30.

12 İkbâlüddin, Tezkire-i Hâce Gîsûdırâz, 32; Nizâmî, “'Gîsûdırâz', 14/95; Kerbelâ-1̂- Nâcî, "Seyyid Muhammed Gîsûdırâz'u-Nakdi Nazariye-i Vahdet-i Vücûd-i İbnü'l-Arâbî”, 50.

13 1347-1527 y1lları arasında Hindistan'ın Dekken bölgesinde hüküm süren bir hânedan. Enver Konukçu, "Behmenîler”, Türkiye Diyanet Vakfi İslâm Ansiklopesi, (İstanbul: TDV Yayınları, 1992), $5 / 353$. 
Doksan yaşında Gülberge'ye gelen Gîsûdırâz, on yıl gibi bir süre içeresinde orayı Çiştiyye'nin merkezi haline getirmeyi başarmıştır. ${ }^{14}$

Çok yönlü bir âlim olan Gîsûdırâz, özellikle Kur'ân, hadis, tasavvuf ve fıkıhla ilgili birçok kitap kaleme almıştır. Ayrıca başta Arapça, Sanskritçe, Farsça ve Hintçe olmak üzere farklı dilleri öğrenmiş ve bu diller sayesinde yogilerle dinî konularda münazarada bulunmuştur. ${ }^{15}$

Hakikatlerin sırlarını kendine hâs bir üslupla ifade eden müellifin, tasavvuf hakkında Arapça ve Farsça yazdığı eserlerin isim listesi şu şekildedir:

1. el-Ma'ârif: Şehâbeddin es-Sühreverdî'nin (öl. 632/1234) 'Avârifü'lma'ârif isimli kitabının Arapça şerhidir. Müellif ayrıca söz konusu eseri Farsça olarak da şerh etmiştir.

2. Şerh-i Ta'arruf: Kelâbâzî’nin (öl. 380/990) et-Ta'arruf unun Farsça şerhidir.

3. Terceme-i Âdâbü'l-mürîdîn: Ebü'n-Necîb es-Sühreverdî’nin (öl. 563/1168) Âdâbü'l-mürîdîn isimli kitabının Farsça tercümesidir. Gîsûdırâz, söz konusu eseri daha önce birkaç defa Farsça'ya tercüme ettiğini fakat bunun son tercüme olduğunu belirtmiştir. Gîsûdırâz ayrıca bu kitaba elHâtime adıyla Arapça bir şerh de yazmıștır. Bu eseri kısa bilgilerle izah eden müellif yer yer tercüme etmekle yetinmiştir. Zaten görüldüğü üzere bu eserine şerh değil, Terceme-i Âdâbü'l-mürîdîn adını vermiștir. ${ }^{16}$

4. Şerh-i Temhîdât: Aynülkudât el-Hemedânînin (öl. 525/1131) Temhîdât'ının Farsça şerhidir. Müellif, bu eserinde İbnü'l-A'râbîyi (öl. 638/1240) eleştirmiştir.

5. Şerh-i Risâle-i Kuşeyriyye: Müellif, bu eseri hem Farsça hem de Arapça olarak şerh etmiştir. Bu şerhinde zâhir ehlinin, âriflerin bazı sözlerinin dinin yıkılmasına ve inançsızlığa yol açtığını bu yüzden onlara bir reddiyye mahiyetinde yazdığını ifade etmiştir. Bu eseri tevekkül babına kadar şerh etmiştir. Ancak eserin hepsini niçin şerh etmediğine dair bir bilgi yoktur. ${ }^{17}$ Bu eserinde yer yer Kuşeyrî’yi (öl. 465/1072) ve adı geçen diğer sûfîleri eleştirirken, Cüneyd-i Bağdâdî’nin (öl. 297/909) düşüncelerini eleştirmekle birlikte onu takdir ettiği görülmüştür. ${ }^{18}$

${ }^{14}$ Gîsûdırâz, Şerh-i Cevâmi'u'l-Kelim, 48; Muhaddis ed-Dihlevî, Ahbârü'l- Ahyâr fi Esrâri'l-Ebrâr, 264; Kerbelâ-1̂- Nâcî, "Seyyid Muhammed Gîsûdırâz'u-Nakdi Nazariye-i Vahdet-i Vücûd-i İbnü'lArâbî", 51 .

${ }^{15}$ Nizâmî, “'Gîsûdırâz', 14/95; Mühsin Muhammedî Feşâreki- Meryem Şîrânî, "Tetebbü-i der Şerhi Gîsûdırâz ez ber Risâle-i Kuşeyriyye”, Neşriyye-i İlmî 1/32 (1396), 72.

${ }^{16}$ Ebü'l-Feth Sadrüddîn Seyyid Muhammed b. Yûsuf el-Hüseynî Gîsûdırâz, Terceme-i Âdâbü'lmürîdîn (Haydarâbâd, 1358), 14.

17 Feşâreki- Şîrânî, “Tetebbü-i der Şerhi Gîsûdırâz ez ber Risâle-i Kuşeyriyye”, 67-69.

18 Feşâreki- Şîrânî, “Tetebbü-i der Şerhi Gîsûdırâz ez ber Risâle-i Kuşeyriyye”, 73. 
6. Hazâirü'l-kuds: ('Işknâme, Haydarâbâd, ts.).

7. Esmârü̈l-esrâr: İsminden de anlaşıldığı üzere bu eserin çoğu yerinde kapalı ifadeler kullanılmışır. Yer yer müellif bazı açıklamalarda bulunsa da genellikle mukattaa harfleri kullanmıştır. ${ }^{19}$ Muhaddis ed-Dihlevî (öl. 1052/1642), Gîsûdırâz'ın bu eserde tasavvufun esrar ve hakîkatlerine remz ve îmâlı lafızlarla işaret ettiğini söylemiştir. ${ }^{20}$ Bazı sûfîler Hindistan tasavvufunda bu eserden daha kıymetli bir eser yazılmadığını söylemişlerdir. Bu eserde zikir, murâkabe, ilâhî aşk ve tevhîd gibi birçok tasavvuf konusu ele alınmıştır. Müellif, kitabın başında bazı hür ruhlu insanların ilâhî sırlara vakıf olmaları için bu eseri kaleme aldığını ve bu eserin bir nevi işaret yoluyla kendisine yazdırıldığını belirtmiş ve bu kitabın önemini şu cümlelerle ifade etmeye çalışmıştır: "Esmârüll-esrâr adını verdiğimiz bu kitap, asılsız bir şey ona ne önünden ne arkasından yaklaşabilir. Hiç kimse ona ihtilaf etmeyecektir. Bunda ancak tevhîdi tecrîd etmek yani Allah'ın zatını bütün tasavvurlardan, zihinlerdeki hayal ve evhamdan soyutlamak ve tefrîdi ifrad etmek yani hiçbir şeyin sâliki hükmü altına almaması, sâlikin bâtınî alâkalardan ve nefisten sıyrılıp Hak ile olma çabası vardır. Dostlar bunu iyi bilsin ki biz kendimizden bir şey yazmadık. Biz ne fazla ne de eksik sadece yazı sahibinin dediklerini aktardık. Zira Hz. Peygamber'in yolundan gidenlere Hakk Teâlâ tarafından kendisine bazı esrâr ve işaretler nasip olur" demiştir. Bir nevi Kur'ân'ın işârî yorumu olan bu eser, Kur'ân sûrelerine uygun bir şekilde yüz on dört semer (gece sohbeti)den meydana gelmiştir. ${ }^{21}$

8. Mektûbât: Altmış altı mektuptan meydana gelmiştir. 39. mektup Sultan Fîrûz Şah'a, 66. mektup Mesud Beg Çiştî̀ye gönderilmiş, diğerleri ise genellikle mürîd ve halifelere gönderilmiştir. ${ }^{22} \mathrm{Bu}$ mektuplarında ilâhî aşk, marifet, muhabbet, mürîdin âdâbı ve sünnet-i seniyye'ye ittiba konuları ele alınmıştır.

9. Cevâhir-i 'uşşâk: Abdülkâdir-i Geylânî'nin (öl. 561/1165-66) Risâle-i gavsiyye adlı risâlesinin şerhidir. Bu risâleyi satır satır kaleme alarak Farsça şerh eden ve metindeki önemli bulduğu istılahlarla ilgili geniş açılamalar yapan Gîsûdırâz, sık sık Farsça beyitlere yer verip önceki sûfîlere de atıfta bulunarak eseri telif etmiştir. ${ }^{23}$

${ }^{19}$ Ebü'l-Feth Sadrüddîn Seyyid Muhammed b. Yûsuf el-Hüseynî Gîsûdırâz, Esmârü'l-Esrâr (Haydarâbâd, 1350), Mükaddime, 2.

${ }^{20}$ Muhaddis ed-Dihlevî, Ahbârü'l- Ahyâr fi Esrâri'l-Ebrâr, 272.

${ }^{21}$ Gîsûdırâz, Esmârü̈'l-Esrâr, 2-3.

${ }^{22}$ Ebü'l-Feth Sadrüddîn Seyyid Muhammed b. Yûsuf el-Hüseynî Gîsûdırâz, Mektûbât-i Gîsûdırâz (Haydarâbâd, 1362), 2.

${ }^{23}$ Nedim Tan- Nazire Kırmızı, "Abdülkâdir Geylânî ve İbnü'l-Arabî̀ye Nispet Edilen Bir Metin: Gavsiyye Risâlesi Hakkında Bir Literatür Değerlendirmesi”, Kocaeli Üniversitesi İlahiyat Fakültesi 
10. Enîsü'l-'uşşâk: Gîsûdırâz'ın şiirlerini ihtiva etmiştir. Aslında kendisinin şiirlere pek meyilli olmadığını ancak hâlin galebe çalması esnasında dilinden döküldüklerini söylemiştir. Zaten bu dîvânı kendisi bir araya getirmemiş en küçük oğlu Seyyid Asgar Hüseynî kitap haline getirmiştir. Bu dîvân toplamda 327 gazel, 26 mesnevî şiiri ve dokuz rubaiden meydana gelmiştir. $^{24}$

11. Cevâmi'u'l-kelim: Müellifin sohbetlerinden meydana gelen bu eser, büyük oğlu Seyyid Muhammed Ekber Hüseynî tarafından derlenmiştir. ${ }^{25}$ Bu eserde sahâbenin fazileti, önceki sûfîlerin sözleri, rü’yetullah, semâ, vahdet-i vücûd ve vahdet-i şuhûd gibi tasavvufun önemli meselelerine değinilmiştir.

12. Şerhu'l-fikhu'l-ekber: Ebû Hanîfe'ye (öl. 150/767) nisbet edilen elFıkhu'l-Ekber adlı eserin şerhidir.

13. Mecmû́ $a$-i yâzde resâ'il: Bu eserde yer alan on bir risâlenin ilk altı tanesi Gîsûdırâz, diğerleri ise Muzaffer-i Belhî tarafından kaleme alınmıştır.

14. Şikârnâme: Tasavvufî roman tarzında olan bu eser dört kardeş hakkında yazılmıștır. Büyük oğlu Muhammed Ekber bu esere bir şerh yazmıştır. $^{26}$

Mi'râcü'l-'âşılkîn adlı eser, Gîsûdırâz'a atfedilmekle birlikte bunun ona aidiyeti net değildir. Kaynaklarda ona ait olduğu belirtilen Şerhu Fusûsi'lhikem ise günümüze ulaşmamıştır. ${ }^{27}$

Ardında birçok eser ve birçok halife bırakan Gîsûdırâz, 16 Zilkade 825'te (1 Kasım 1422) yüz beş yaşında Gülberge'de vefat etmiştir. Ahmed Şah Behmenî tarafından kabri üzerine bir türbe inşa edilmiştir. ${ }^{28}$

\section{Bazı Tasavvufî Görüşleri}

Gîsûdırâz, on beş on altı yaşlarında dönemin önde gelen Çiştiyye meşâyihinden Çırâğ-1 Dehlî̀ye intisab edip otuz yaşında ondan hilâfet icazetini alır. Yirmi bir yıl onun hizmetinde bulunan Gîsûdırâz, Çırâğ-1 Dehlî’nin önde gelen halifeleri arasında kabul edilir. ${ }^{29}$

Dergisi 1/1 (2017), 25.

${ }^{24}$ Ebü'l-Feth Sadrüddîn Seyyid Muhammed b. Yûsuf el-Hüseynî Gîsûdırâz, Enîsü'l-'Uşşâk (Haydarâbâd, 1360), 8.

${ }^{25}$ Gîsûdırâz, Şerh-i Cevâmi'u'l-Kelim, 43.

${ }^{26}$ Feşâreki- Şîrânî, “Tetebbü-i der Şerhi Gîsûdırâz ez ber Risâle-i Kuşeyriyye”, 73.

27 Nizâmî, “'Gîsûdırâz', 14/95; Kerbelâ-1̂- Nâcî, “Seyyid Muhammed Gîsûdırâz'u-Nakdi Nazariye-i Vahdet-i Vücûd-i İbnü'l-Arâbî”, 51.

${ }^{28}$ Nizâmî, “"Gîsûdırâz', 14/94; Feşâreki- Şîrânî, "Tetebbü-i der Şerhi Gîsûdırâz ez ber Risâle-i Kuşeyriyye”, 71.

${ }^{29}$ Gîsûdırâz, Şerh-i Cevâmi'u'l-Kelim, 48; Feşâreki- Şîrânî, "Tetebbü-i der Şerhi Gîsûdırâz ez ber Risâle-i Kuşeyriyye”, 70; Kerbelâ-1̂- Nâcî, "Seyyid Muhammed Gîsûdırâz'u-Nakdi Nazariye-i Vahdet-i Vücûd-i İbnü'l-Arâbî”, 50. 
"Tasavvuf bir hâl ilmidir, kâl ilmi değildir" şeklindeki vecize, bazı çevrelerce tasavvufun ilme önem vermediği şeklinde bir algıyı gündeme getirmiştir. Halbuki Cibrîl hadisinde geçen ihsan mertebesine denk olan tasavvuf yolunun, zâhirî ilimleri tahsil etmekten geçtiğini ifade etmek gerekir. Aksi takdirde o ilimleri tahsil etmeyenin mürşid olma yetkisinin olmadığını belirtmek gerekir. Her ne kadar cahil insanlar sûfîlik iddiasinda bulunsalar dahi bunun yersiz olduğunu söylemek gerekir. Çünkü bu yolda ilimsiz mesafe kat edilmeyeceği tecrübelerle sabittir. Bu bağlamda Gîsûdırâz, tasavvufun ciddi bir alan olduğunu bu yüzden bu yola ilimsiz adım atılmayacağını aksi takdirde bu alana yani tasavvufa ilimsiz bürünenlerin ömürlerinin sonunda ya deli ya da Allah korusun kâfir olma risklerinin yüksek olduğuna dikkat çeker. Zira mürîdin ilm-i billah olan tasavvufa ilimsiz girmesi halinde vesveselerle müptela olma tehlikesi vardır. Öyle ki namaz esnasında niyette o kadar mübalağa eder ki namaz vaktini dahi geçirdiğini belirtir. Halbuki müellif, dil ile niyet etmenin sünnet olduğunu ancak sünneti eda edeyim derken farzı kaçırdığını hatta bazılarının abdestim tam olmadı diye namazlarını sürekli kaza ettiklerini söyleyerek durumun vahametine vurgu yapar. ${ }^{30}$

\section{1. Şerîat- Tarîkat}

Tasavvufun İslâmî ilimler içerisindeki konumu, şeriat ile olan münasebeti ve İslâm dairesi içerisinde nereye yerleştirileceği hususu tasavvufun İslâmî ilimler arasında tebarüz etmeye başladığı ilk zamanlardan günümüze kadar tartışılmıştır. Gerek sûfîler, içerisinde şeriata aykırı bazı görüşlerin ortaya çıkması, gerekse tasavvuf konusundaki yanlış algılamalar karşısında sûfîler şeriata uygun bir tasavvuf anlayışını ortaya koymak adına eser telifine girişmişlerdir. ${ }^{31}$ Zaman zaman şeriat ve tarîkat karşılaştırılması yapılıp bunların aynı mı yoksa farklı şeyler mi diye tartışıldı̆̆ı görülür. Çiştiyye şeyhleri arasında kendine has bir metodu olan Gîsûdırâz buna şu şekilde açıklık getirir: "Şerîat, kâmil insanın sözlerine, tarîkat ise kâmil insanın fiillerine denilir." ${ }^{32}$ Bununla şerîat ile tarîkatın aynı şey olduğunu, birisinin İslâm'ın nazarî yönünü diğerinin ise amelî yönünü temsil ettiğini ve bunları birbirinden farklıymış gibi göstermenin gereksiz olduğunu ifade etmeye çalışır. ${ }^{33}$ Ayrıca müellif, bunları birbirinden

${ }^{30}$ Gîsûdırâz, Şerh-i Cevâmi'u'l-Kelim, 243.

${ }^{31}$ Mahmud Esad Erkaya, “III. Uluslararası el- Farabi Sosyal Bilimler Kongresi” (Ankara: İksad Yayınlar1, 2018), 362.

32 Gîsûdırâz, Mecmû́a-i Yâzde Resâ'il (Hadâikü'l-Üns), 70.

${ }^{33}$ Ebü'l-Feth Sadrüddîn Seyyid Muhammed b. Yûsuf el-Hüseynî Gîsûdırâz, Mecmû́a-i Yâzde Resẩil (Risâle-i İstikâmeti Şeriat bı Tarîk-i Hakikat) (Haydarâbâd, 1941), 24. 
ayırmanın yanlış olduğunu badem örneği üzerinden açıklamaya çalışır: "Bademde kabuk, iç ve yağ bulunmaktadır. Bunlar birbirinden farklı şeyler değildir. Nitekim iç, kabuğun özü, yağ da "iç" için öz mesabesindedir. Aynı şekilde tarîkat, şerîatın özü iken hakikat da tarîkatın özüdür" der.

Tasavvuf yoluna girmeden önce zâhîrî ilimlerin tahsili önemli görülmüştür. Bu yüzden sûfîlerin bu yola girmek isteyen sâliklere önce medrese yolunu gösterdikleri daha sonra da tekkeye aldıkları görülür. Bu çizgiyi takip eden Gîsûdırâz, şerîati öğrenmeden tarîkata girenlerin sonunun, tarîkat yolunda hiçbir ilerleme kat etmedikleri gibi aksine mânevî konuda geriye gittiklerini ifade eder. Hatta imanlarının bile tehlike de olduğunu ve şeytanların maskarası olduklarını belirtir. ${ }^{34}$

İnsanların birbirileriyle sağlıkl iletişim kurabilmeleri için dil önemlidir. Bu yüzden tarih boyunca davalarında başarılı olan insanların gittikleri bölgelerde yerli dilleri öğrenmekle işe başladıkları görülür. Bu yüzden farklı coğrafyalara irşad için giden sûfîlerin de aynı metodu uyguladıklarını söyleyebiliriz. Nitekim bu konuya dikkat çeken Gîsûdırâz, Hz. Âdem'den Peygamber efendimize kadar olan süreçte gelen tüm peygamberlerin davalarının insanları tevhide davet etmek olduğunu ve her peygamberin kendi kavminin diliyle halkını talim ettiğini belirtir. Zamanın şartlarına göre şerîatın hükümlerinde farklılık olsa da şerîatın esasının ve temelinin hep tevhid olduğunu ifade eder. Bu şekilde tüm peygamberlerin topluma kulluğu öğrettiklerini ve tabii ki tüm peygamberlerin davet ettiği bu dinin temellerini vahiy üzere bina ettiklerini söyler. Yani peygamberlerin emr ve nehiy ettikleri tüm kuralların adı şerîat olduğunu tarîkatın ise şerîatın zâhirî ahkamını tezkiye ve saflaştırmak olduğunu belirtir. Çünkü tarîkatın bâtının tezkiye ve tasfiyesi ile meşgul olduğunu belirttikten sonra konunun daha iyi anlaşlabilmesi için şu örneği verir: "Malumunuz şerîatın ahkamına göre namaz için elbiselerin necasetten temiz olmaları gerekir. Tarîkatın ahkamı ise namaz esnasında gönlün tüm kirlerden temiz olması icap eder. Bu yüzden şerîat ve tarîkatın asıl çabalarının kişinin zâhirini temiz tutarak bâtının temizliğine ulaşmasıdır. Yani şerîat, tarîkatın ilk adımı, tarîkatta hakikatın ilk adımıdır diyebiliriz" şeklinde belirterek her ne kadar isim farklılığı olsa da aslında aynı yere çıktıklarını ifade etmeye çalışır. ${ }^{35}$

\subsection{Nübüivvet-Velâyet}

Nübüvvet-velâyet meselesini ilk defa gündemine alan sûfînin Ebu

${ }^{34}$ Hüseyin, Sîret-i Pâk Hazret-i Seyyid Muhammed Gîsûdırâz, 86.

${ }^{35}$ Hüseyin, Sîret-i Pâk Hazret-i Seyyid Muhammed Gîsûdırâz, 87. 
Süleyman ed-Dârânî (öl. 215/830) olduğu söylenir. Daha sonra Hatmu'levliyâ'nın müellifi olan Hakîm Tirmizî de (öl. 320/932) bu konuya değinir. ${ }^{36}$ Böylece ilk dönemden itibaren sûfîlerin dikkatini çeken bu kavramlar üzerinde farklı görüşlerin ileri sürüldüğü görülür. Nitekim bu konuya yabancı kalmayan sûfîlerden biri de çalışmamıza konu olan Gîsûdırâz'dır. Zira o, velâyetin hiçbir zaman nübüvvetten üstün olmadığını velâyetin son derecesinin nübüvvet basamağının ilk derecesi olduğunu belirtir. ${ }^{37}$ Ona göre velâyet makamından maksad, marifetullah yani Yüce Allah'ı hakkıyla tanımak ve O'nun katındaki hakikatlere muttalî olmaktır. Ayrıca o, velâyetin son aşamasının nübüvvetin ilk derecesi olduğunu zira her nebînin öncelikle velâyet makamının en son mertebesine ulaştığını daha sonra nübüvvetin ilk makamına geçtiğini ancak nübüvvetin nihayet derecesine hiçbir velînin ulaşamadığına dikkat çeker. Fakat bununla birlikte aşk ehli olan bazı sûfîlerin iki açıdan Hz. Peygamberin ümmetinden olan evliyânın önceki bazı peygamberlerden daha üstün olduklarını iddia ettiklerini aktarır: "Iddia ettikleri birinci neden velînin; marifetullah, kurbiyet ve hakikatlere muttalî olması sebebiyle yüzünün Hakk'a dönük olduğunu ancak nebînin ise halk ile ilgilendiğini bu yüzden Hakk'a dönük olan velînin halka dönük olan nebîden daha üstün olduğunu ileri sürdüklerini söyler. Bunların görüşlerine katılmayan Gîsûdırâz, bundan velînin nebîden üstün olduğu anlamının çıkmadığını zira halka tebliğ etmenin nübüvvetin bir rüknü olduğunu hatta nübüvvetin aslî vazifesi olduğunu belirtir. Ayrıca müellif, peygamberlerin halk ile ilgilendikleri zaman diliminde marifetten yoksun oldukları anlamına gelmediğini ifade eder. Zira tebliğin de marifetin bir parçası olduğunu söyler. Bunun yanı sıra marifet ve kurbiyetin en yüksek derecesinin peygamberlerde gerçekleştiğine dikkat çeker. Bu yüzden velînin kurbiyetinin nübüvvet ile desteklenmediğinden dolayı velînin muttalî olduğu hakikatlerin gerçekleşmesinin kesin olmadığını fakat ismet sahibi olan peygamberlerin gördüğü hakikatlerin gerçekleşmesinin kesin olduğunu belirtir. Gîsûdırâz, nübüvvetin her zaman vahiy ile desteklendiğinden ve süreklilik arz ettiğinden velâyetten üstün olduğunu söyler. Zira Hz. İsa'nın beşikte meâlen "Şüphesiz ben Allah'in kuluyum. Bana kitabi (Incil'i) verdi ve beni bir peygamber yaptl." ${ }^{38}$ ifadesinin nübüvvetin vahiy ile desteklendiğine ve süreklilik arz

36 Salih Çift, “Tasavvufta Velâyet Kavramı: Hakîm Tirmîzî Örneği”, Bursa'da Dünden Bugüne Tasavvuf Kültürü - 2 (İstanbul: Graphis Matbaa, 2003), 134.

${ }^{37}$ Kerbelâ-1̂- Nâcî, “Seyyid Muhammed Gîsûdırâz'u-Nakdi Nazariye-i Vahdet-i Vücûd-i İbnü’lArâbî”, 52.

38 Meryem 19/30. 
ettiğine işaret ettiğini belirtir. ${ }^{39}$ Ayrıca "Andolsun, Allah, mü’minlere kendi içlerinden; onlara âyetlerini okuyan, onları arıtıp tertemiz yapan, onlara kitab ve hikmeti öğreten bir peygamber göndermekle büyük bir lütufta bulunmuştur." 40 mealindeki ayetin, nebîlerin evliyâya olan üstünlüğünü gösterdiğini ifade eder. Gîsûdırâz: "Bu divâne olan dervişlerin diğer ileri sürdükleri iddia ise; Müslümanlar içerisinde bazı kişilerin Hz. Peygambere karşı samimiyetlerinden ötürü önceki peygamberlere nasip olmayan makamların bunlara nasip olduğunu ileri sürerler. Zira Hz. Musa'nın “Allâh'ım! Beni de ümmet-i Muhammed'den eyle!” sözünün bunu ispatladığını söylerler. Bunların bu sözüne karşı çıkan Gîsûdırâz, bunlara reddiye mahiyetinde şöyle der: 'Bu, aşkın galebe çalması esnasında söylenmiş bir sözdür, o halde söylenmemiş olsa bile, yine de velâyetin nübüvvetten daha üstün olduğu anlamı çıkmaz." ${ }^{41}$

Son olarak peygamberlerin nübüvvet ve velâyet meselesine değinen Gîsûdırâz, nübüvvetin mutlak anlamda velâyetten üstün olduğu kanaatindedir. Çünkü ona göre, peygamberlere hâs bir şekilde hem nübüvvet hem de velâyet yönlerinin olduğunu bu yüzden her nebînin bir de velîlik yönü olduğunu beyan eder. Konuyu temellendirmek için insan tanımındaki "hayvan-1 nâtık" sözcüğü özerinden açıklık getirmeye çalışarak şöyle der: "Insan tanımı "hayvan-1 nâtık" şeklinde yapılır. Bu yüzden insana hayvan denilebilir, ancak hayvana insan denilemez. Öyle ise nebîlerin velâyeti onların nübüvvetinden üstündür demek insan tanımındaki hayvanın insandan daha üstün olduğunu iddia etmek gibidir" sözüne benzer. ${ }^{42}$

\section{3. İlâhî Aşk}

Aşk; tasavvufî, edebî, felsefî çevreler tarafından ele alınan önemli bir kavramdır. Kur'ân-1 Kerîm'de ve ilk tasavvufî kaynaklarda aşk, daha çok muhabbet olarak ifade edilmektedir. Muhabbet, Allah'ın kuluna olan sevgisinin, rahmetinin ve merhametinin tecellisi olarak tezâhür etmektedir. Bu meyanda Allah, hem âşık hem mâşûk yani hem seven hem de sevilen bir varlıktır. Kur'ân-1 Kerîm'de bu husus, “....Allah'ın onları seveceği, onların da Allah'ı seveceği bir topluluk..." ${ }^{43}$ başka bir ayette, "Insanlar arasında Allah'ı bırakıp da O'na ortak koşanlar vardır. Onları, Allah'ı severcesine severler. Mü'minlerin Allah'a olan sevgisi daha güçlü bir sevgidir." ${ }^{44}$

${ }^{39}$ Gîsûdırâz, Mektûbât-i Gîsûdırâz, 127.

40 Âl-i İmrân 3/164.

${ }^{41}$ Gîsûdırâz, Mektûbât-i Gîsûdırâz, 124.

${ }^{42}$ Gîsûdırâz, Mektûbât-i Gîsûdırâz, 128.

43 el-Mâide 5/54.

${ }^{44}$ el-Bakara 2/165. 
Şeklinde zikredilmiştir. ${ }^{45}$ ilk mutasavvıflar aşk1, muhabbet kelimesiyle tanımlamışlardır. Muhabbet ise fenâ (Allah'da fâni olma) vâdilerinin evveli olup, mahviyet menzillerine doğru inilen bir süreç olarak kabul edilmiştir. ${ }^{46}$ İnsanoğlunun nefsine hiçbir şey, hayır olsun şer olsun sohbet kadar müessir değildir. Bu yüzden Gîsûdırâz, kulda ilâhî aşkın meydana gelebilmesi için kişinin âşıkların sohbetinde bulunması gerektiğini zira "Âşıklarla otur âşı olursun" sözünün bunu ifade ettiğini belirtir. Âşıların sürekli aşk ile ilgili sözleri sarf etmelerinden sâlikin üzerinde hızlı bir değişim meydana geleceğini ifade eder. Ayrıca sâlikin onlardan dinlediği sözler sayesinde gönlünde ilâhî muhabbetin ateşi alevlenmeye başlayacağını ve böylece aşk ve muhabbet yolunda adım adım ilerlemeye başlayacağını ifade eder. Nitekim "Kulak gözden önce âşık olur" sözünün buna işaret ettiğini çünkü çoğu defa âşığın, sevgiliyi görmediği halde hüsn-i cemâlinin anlatılmasıyla âşık olduğunu belirtir. Aynı şekilde âşıklar ve Hak dostları ile oturmakla ilâhî aşkın elde edileceğini zira sâlikin, sevgilinin hüsn-i cemâlini dinlemeye başlamasıyla aşkın kıvılcımları gönlünde yükselmeye başlayacağını ifade eder. Bu yüzden sadık âşıklarla sürekli kalkıp oturmaya çalışan kişinin Hakiki Mahbûb'un cemâlinde gark olacağını belirtir. Zira sâlikin bu durumda bütün varlığıyla o tarafa yöneldiğini, kendi varlığının yok olduğunu ve bu şekilde her an Dost ile muhabbet bağını kurduğunu ifade eder. Böylece gayb kapıları gönlünde açılacağını ve daha sonra mahbûbun cemâli kendisine nasip olacağını ve artık sadık âşıklar ve kâmil dostlardan sayılacağını söyler. ${ }^{47}$

Gîsûdırâz, aşkı tavsiye ederken, aşkın tehlikesine de dikkatimizi şöyle çekmiştir: "Her şeyin tehlikesi olduğu gibi aşkın da başta ve sonda olmak üzere iki tehlikesi bulunur. Başlangıçtaki tehlike, maşûkun aşk1, âşı̆̆ın dimağında öyle bir yer edinir ki uzun süre onun ateşiyle yanıp tutuştuktan sonra tam lezzet kendisine müyesser olur. Fakat daha sonra visâl gerçekleşmeyince sâlik dert ve elem çekmeye başlar. Uzun zaman böyle kalınca elem ve acı onun tabiatı haline gelir. Böylece acı ve elemin zevkini tatmaya başlar. Daha sonra bu zevki de kaybetmeye başlar. Bu nedenle ne visâl gerçekleşmiş ne de dertten zevk almak. Ve bu şekilde tekrar başa dönüp hüsran ile sonuçlanır. ${ }^{48}$ İntihâdaki tehlike ise sâlike visâl nasip olduktan sonra onun lezzeti ile meşgul olup firâk ve hicran ondan uzaklaşır. Ancak

${ }^{45}$ Nuran Çetin, "Müştâk Baba ve Kuddûsî Baba Dîvânlarında illâhî Aşk Anlayışı Üzerine Değerlendirme", Hitit Üniversitesi İlahiyat Fakültesi Dergisi 18/35 (2019), 237.

${ }^{46}$ Hâce Abdullah el-Ensârî, Menâzilü's-sâirîn, çev. Abdurrezzak Tek (Bursa: Emin Yayınları, 2017), 57.

${ }^{47}$ Gîsûdırâz, Serh-i Cevâmi'u'l-Kelim, 489.

${ }^{48}$ Gîsûdırâz, Şerh-i Cevâmi'u'l-Kelim, 489. 
bir süre sonra visâl onun tabiatı haline geldikten sonra visâlin zevkini de almamaya başlar. Zira yaşamın amacı visâlin zevk ve şevkini yaşamaktır. Ancak hem visâl hem de hicrandaki maksat olan zevk ve şevk yok olduktan sonra artık her ikisinden yani visâl ve hicrandan da zevk ve lezzet almamaya başlar. Neticede artık bununda faydası kalmaz, sâlikin ateşi söner, aşkı gider ve mahbûbun cemâl zevkinden mahrum kalır. Peki o zaman âşık ne yapmalıdır onun için hangi durum daha iyidir? Âşık, ibtidâ ve intihâda da firâk ve elem zevkini korumalıdır. Bu şekilde kurbiyet ve visâl artıkça onun şevk ve zevki de artıp daha da fazlasını talep eder. Böylece dert üstüne dert, zevk üstüne zevk yaşar. İşte bu tür âşık hangi durumda olsa akıbet onun için hayırlı olur. Zira aşk için en iyi durum bazen firâk ateşini bazen de visâl lezzetini yaşamaktır" der. ${ }^{49}$

\subsection{Kerâmet}

Bir tasavvuf terimi olarak kerâmet, peygamberlik iddiası olmaksızın bir kişide harikulâde bir halin ortaya çımasıdır..$^{50}$ Tasavvufta kerâmet, 'kevnî, sûrî, maddî' veya 'hakiki, ilmî, manevî' olmak üzere ikiye ayrılır. Kevnî kerâmet, bazı olağanüstü haller göstermektir. Havada uçmak, denizde yürümek, gönülden geçeni bilmek gibi. Hakikî kerâmet ise; ilim, mârifet ve ahlakla ilgili olağan üstü durumlardır. Bütün bu ifadeler göz önünde bulundurulduğunda peygamberler, istediklerizaman mucize açığa çıkarmaya muktedirdir; yani mucizenin gösterilmesi vaciptir. Kerâmetin ise, gizli olması gereklidir. Mucize de kerâmet de bütün fiiller gibi Allah takdir ederse gerçekleşir. ${ }^{51}$ Kerâmetin gizliliği esas olduğundan sûfiler, kerâmeti 'hayz-1 ricâl' olarak görmüşlerdir. Kerâmeti inkâr edenler, velî ve peygamber arasındaki tek farkın, peygamberin başkaları tarafından gerçekleştirilmesi mümkün olmayan mûcize fiilleri gerçekleştirmesi olduğunu sanmışlar ve "Eğer bunu evliyâ için de mümkün görürsek, nebi ve velî arasında fark kalmaz" demişlerdir. Buna cevaben Gîsûdırâz, velinin kerametini kabul etmek gerektiğini, kerâmeti yok saymanın Allah'in kudret sıfatını inkâr etmeyi içerdiğinden bunun doğru olmadığını belirtir. ${ }^{52}$ Gîsûdırâz: "Kerâmet olağanüstü yani adet dışı şeylerden ibârettir. Yoksa muhalı ispat etmek değildir" der. Bunun daha rahat anlaşılabilmesi için Gîsûdırâz şu örnekleri verir; "Yaz meyvesi yazın, kış meyvesi kışın bulu-

49 Gîsûdırâz, Şerh-i Cevâmi'u'l-Kelim, 489.

${ }^{50}$ Ethem Cebecioğlu, Tasavvuf Terimleri ve Deyimleri Sözlüğü (İstanbul: Anka Yayınları, 2005), 446.

${ }^{51}$ Esma Sayın, “Tasavvufî Kavramlarla Anlamsal Bağları Açısından Kerâmet Kavramı”, Balıkesir İlahiyat Dergisi 12 (2020), 239.

${ }^{52}$ Gîsûdırâz, Mecmû'a-i Yâzde Resâ’il (Risâle der Mesele-i Rü'yet-i Bârî Taâlâ’u-Kerâmâti Evliyâ), 51. 
nur, ilginç olan kış meyvesinin yazın, yaz meyvesinin de kışın bulunmasıdır. Suyun tabîatı gereği ağır şeyler suda batar, kerâmet olan ise olağanüstü bir şekilde su üzerinde kalmaktır. Bunun bir benzeri de hâfız olan kimsenin bir gecede Kur'ân'ı bi kaç defa hatmetmesidir." ${ }^{53}$

Tasavvuf ehli nezdinde kerâmet göstermenin bir marifet olmadığı asıl olanın sâlikin istikâmet ve muhabbet üzere olmasıdır. Zira onlara göre sâlikin keşf ve kerâmetlerini gizlemesi, istikamet ve muhabbet yolunda gitmesi esastır. Çünkü kerâmetini izhar edenin tasavvuf yolundaki bir farzı terk ettiğini ve de kötü bir şey yaptığını ifade ederler. ${ }^{54}$ Gîsûdırâz, peygamberlerin mûcizeleri gibi evliyânın kerâmetlerinin de hak olduğunu kabul eder ve mûcizelerin izhârının esâs olduğunu kerâmetlerin ise gizli kalmasının gerekliliğ̈ini belirtir. Müellif, sûfî büyüklerinin prensiplerinin bu olduğunu ve onların kerâmeti izhar etmekten sürekli kaçtıklarını ifade eder. Elbette gaybî işaret ve İslâm'ı tebliğ etmek amacı ile kerâmeti izhar etmede bir problem olmadığııı belirtir. ${ }^{55}$

\subsection{Nefis Mertebeleri}

Sûfîler nefs terimiyle, kulun kötü özellikleriyle yerilen, kınanan, hoş karşılanmayan ve kötü görülen huy, fiil, davranış ve eğilimlerini kastederler. Mutasavvıflar güzel ahlâkın zıddı olan kötü huyların ve çirkin davranışların kaynağını nefs olarak görmüşlerdir. ${ }^{56}$ Bedende kaç nefis olduğu konusu tartışılmakla birlikte genel kanaate göre bir bedende bir nefsin bulunduğu ancak kötülüğü emretme ve kınama gibi farklı sıfatlara sahip olduğu görüşü savunulmaktadır. Diğer bir kısım sûfîlere göre ise bir bedende emmâre, levvâme ve mutmainne olmak üzere üç farklı nefsin mevcut olduğu ve bu nefislerin sürekli mücadele ettikleri ileri sürülmektedir. ${ }^{57}$ Gîsûdırâz, nefsin üç mertebesi olduğunu fakat bunun üç farklı nefis şeklinde anlaşılmaması gerektiğini zira nefsin bir tane olduğunu ancak farklı hal ve mertebelerden ibaret olduğunu ve bu şekilde halden hale girip isim değişikliğine uğradığını belirtir. Ona göre bütün nefislerin temeli, nefs-i emmâredir. Ancak mücâhede, riyâzat ve nefis tezkiyesi ile levvâme mertebesine dönüştüğünü ardından da mutmainne mertebesine yükseldiğini belirtir. Fakat bütün peygamberlerin nefislerinin mutmainne mertebesinde olduğunu savunur. Peki Hz. Yusuf gibi nefsini aşă̆ıllayan peygam-

\footnotetext{
${ }^{53}$ Gîsûdırâz, Mecmû‘ a-i Yâzde Resâ’il (Risâle der Mesele-i Rü'yet-i Bârî Taâlâ'u-Kerâmâti Evliyâ), 50.

54 Sayın, “Tasavvufî Kavramlarla Anlamsal Bağları Açısından Kerâmet Kavramı”, 239-251.

55 İkbâlüddin, Tezkire-i Hâce Gîsûdırâz, 76.

${ }^{56}$ Abdulkerim b. Havâzin Kuşeyrî, Kuşeyrî Risâlesi (İstanbul: Semerkand, 2019), 232.

${ }^{57}$ Süleyman Uludağ, "Nefis", Türkiye Diyanet Vakfi Islâm Ansiklopedisi (İstanbul: TDV Yayınları, 2006), 32/526-529.
} 
berlere ne dersin sorusuna şöyle cevap verir: “Bu, Hakk'a karşı kendi acziyetini ifade etmek için söylenmiş bir sözdür" der. ${ }^{58}$

\subsection{Semâ}

Tasavvuf literatüründe semâ, dinlenen ilâhînin, müziğin veya kâinâttaki herhangi bir ritmik sesin etkisiyle coşup dönme anlamını ifâde eder. İlk zamanlar dinlenen müziğin veya gazelin etkisiyle, bir kurala bağlı olmaksızın kalkıp dönülmesi söz konusu iken sonradan, Mevlevîlerde olduğu gibi şeklî bazı kaidelerle düzen altına alınmıştır. ${ }^{59}$ Ayrıca semâ, güzel sesle okunan Kur'ân, ilâhî veya kasideyi dinlemek anlamındadır. ${ }^{60}$ Genel anlamda Çiştiyye tarîkatında şartları yerine getirildiği takdirde raksın bir sakıncası görülmemektedir. Onlara göre, semâ esnasındaki hareket Hakk'ı hatırlatıyorsa müstehaptır. Ancak raks yapanın tabîatı fesada meylediyorsa o zaman kendisine haram olur. Semâ esnasında raks ederken elbisesini yırtmak şayet mağlûbu'l-hâl ise bunu yapan sorumlu tutulmaz, eğer riyâ veya dervişsliğini izhâr etmek için raks edip elbisesini yırtıyorsa kesinlikle haramdır. ${ }^{61}$ Ancak Gîsûdırâz, sûfîlerin semâ yaptıkları sırada oyun havasında yapmalarının doğru olmadığını söyler. Ona göre bu tür şeylerin hiçbirinin hakikatinin olmadığını, bunların beyhude hareketler olduğunu ifade eder. Ayrıca o, semâ esnasında okunan nağmeli ilâhîlere karşı olmadığını ancak Bağdat'ta olduğu sırada sûfîlerin semâ yaptıklarını fakat semâ esnasında hiç hareket etmediklerini sadece Allah, Allah diye zikrettiklerini aktarır. Bunun yanı sıra semâ esnasında gözlerinden akan yaştan başka bir hareket görmediğini ifade eder. ${ }^{62}$

Sûfîler, zikir ve mücâhedelerle yorgun düşen vücûdlarına tekrar güç kazandırarak, zindelik elde etmek için semâ yaparlar. Böylece içlerindeki ilâhî aşk ve muhabbet ateşini ilâhîlerle ve ârifâne beyitleri dinlemekle söndürmeye çalışırlar. Bu duruma dikkat çeken Gîsûdırâz, sûfîlerin semâdan aldıkları zevkin müzik notalarından kaynaklanmadığını zira onların bu tür şeylere aldırmadıklarını belirtir. Çünkü semâdan maksatları Allah ile irtibat kurabilmek olduğunu bu yüzden hale muvafik bir söz veya bir avaz işittiklerinde halden hale girdiklerini ve göz yaşı döküp

\footnotetext{
${ }^{58}$ Gîsûdırâz, Şerh-i Cevâmi'u'l-Kelim, 480.

${ }^{59}$ Cebecioğlu, Tasavvuf Terimleri ve Deyimleri Sözlüğü, 555; Süleyman Uludağ, Tasavvuf Terimleri Sözlüğü (İstanbul: Kabalc1 Yayınları, 2005), 321.

${ }^{60}$ Abdulkerim b. Havâzin Kuşeyrî, Kuşeyri Risalesi, ts., 335.

${ }^{61}$ Geniş bilgi için bk. İsa Çelik - Ömer Tay, "Çiştiyye Tarîkatının Semâ ve Mûsikîye Yaklaşımı”, Çukurova Üniversitesi İlahiyat Fakültesi Dergisi 21/1 (22 Haziran 2021), 210-230.

${ }^{62}$ Gîsûdırâz, Şerh-i Cevâmi'u'l-Kelim, 190; Abdülazîz b. Şîr Melik Vâizî, Târîh-i Habîbî ve Tezkire-i Mürşidî (Haydarâbâd, 2005), 85-89.
} 
dehşete düştüklerini beyan eder. ${ }^{63}$ Ona göre semâ meclislerinde hoş karşılanan durum, halini belli etmemek ve kendini zapt edebilmektir. Ancak bazen gayri ihtiyari hareketlerin sadır olabileceğini fakat bu tür durumlarda sâlikin mazur sayılacağını söyler. Tabii ki bu da tasvip edilen bir şey olmadığını çünkü semâın amacının mâsivayı gönülden atıp tek bir noktaya odaklanmak olduğunu belirtir. Semân, sâliki Hakk'a götüren bir vesile olduğunu, ${ }^{64}$ semâ ehlinin farklı şekillerde farklı haller yaşadığını ancak temekkün ehli olanların bu haller esnasında mağlup olmadıklarını aksine hale galip geldiklerini ifade eder. ${ }^{65}$

\subsection{Bîat}

Tasavvufta bîat, mürşitle yapılan manevî sözleşmedir. Bunun anlamı, Allah'in halifesi olan mürşidle sözleşme yapan mürîdin, mürşidine sadık ve bağlı kalacağına, Allah için Allah yolunda kendisine kayıtsız şartsız teslim olacağına, haramlardan uzaklaşacağına, helal ve hayırlara sarılacağına, günahlardan tövbe edip bir daha yapmayacağına dair söz vermesi, buna Allah'1, Resûlünü ve kâmil mürşidi şahit tutması demektir. ${ }^{66}$ İnsanoğlu tarih boyunca bir muallime, müeddibe ihtiyaç duymuştur. Nitekim peygamberler, âlimler ve ârifler insanlara rehberlik etmişlerdir. Gîsûdırâz, orduya alınan kişinin yanında kılıç, ok ve yay, ilme başlayan kişinin ise yanında kalem, mürekkep ve kâğıt bulundurması gerektiği gibi sûfî olmak isteyenin de muhakkak bir şeyhin eteğine yapışması icap ettiğini belirtir. Tasavvufta gönülden mürşidine bağlı olan mürîdin daha faziletli olduğu söylenir. Bu yüzden Gîsûdırâz, kişinin intisap ettikten sonra muhakkak mürşidinin dediklerini yapması gerektiğini aksi takdirde daha sonra pişman olacağını ve gittikçe şeyhten uzaklaşıp artık faydasını göremez hale geleceğini beyan eder. ${ }^{67}$

Çiştiyye pîrleri, vefat eden pîrlere bîat etmenin doğru olmadığını bu yüzden şeyhin elinin mürîdin eline değmesi ve şeyhin hayatta olması gerektiğini belirtirler ${ }^{68}$ Aynı çizgiyi takip eden Gîsûdırâz, vefat eden mürşidleri ziyaret etmekten fayda hasıl olsa da ölülere bîat etmenin doğru olmadığını muhakkak şeyhin hayatta olması gerektiğini belirtir. Sûfîler tek şeyhe bîat etmenin bilhassa yolun başında olan sâlik için onun soh-

63 Gîsûdırâz, Şerh-i Cevâmi'u'l-Kelim, 260.

${ }^{64}$ Gîsûdırâz, Şerh-i Cevâmicu'l-Kelim, 260.

${ }^{65}$ Gîsûdırâz, Şerh-i Cevâmi'u'l-Kelim, 260.

${ }^{66}$ Uludağ, Tasavvuf Terimleri Sözlüğü, 97; Dilaver Selvi, “Biat Sünnetnin Tasavvufta İhyası”, İhya Uluslararası İslam Araştırmaları Dergisi 1/1 (2015), 3.

${ }^{67}$ Gîsûdırâz, Şerh-i Cevâmi'u'l-Kelim, 260.

${ }^{68}$ Muhammed b. Mübârek b. Muhammed Alevî Kirmânî Mîrhord, Siyerü'l-Evliyâ (Lahor: Müştâk Ahmed Yayınları, 1885), 455. 
betlerine bağlı kalmanın zaruretine dikkat çekerler. Farklı şeyhlerin sohbetlerinde bulunmanın onların metotlarının farklılı̆̆ından dolayı sâlikte psikolojik rahatsılılılara neden olabileceğini söylerler. Bu konuda Gîsûdırâz'a, ikinci pîre bîatın doğru olup olmadığı sorulduğunda şu cevabı vermiştir: "Şayet ilk pîr mürîdini başka bir mürşide yönlendirmişse yani gitmesine izin vermişse ya da mürîdin seyr u sülûku tamamlamadan mürşidi vefat etmişse başka bir pîre intisap etmekte herhangi bir sakıncası yoktur, hatta faydalıdır. Aksi takdirde silsileyi uzatmanın bir anlamı yoktur." ${ }^{69}$

Tasavvufta önemli bir yeri olan bîat konusu zâhir ulemâ ile mutasavviflar arasında çekişmeye neden olmuştur. Fakat sûfîler bîatın İslâm'in kurallarına ters düşmediğini, Hz. Peygamber tarafından farklı zamanlarda sahabîlere bîat verildiğini ifade ederler. Gîsûdırâz'a intisap etmek için gelenlere ise şu şekilde bîat verdiği aktarılır: "Sağ elini onların sağ elinin üzerine bırakıp daha sonra kendisinden başlayıp silsiledeki tüm şeyhlerin ismini zikrettikten sonra gözlerini, dilini haramlardan muhafaza edeceğine ve şerîata bağlı kalacağına dair müritten söz alırdı. Mürîd de bunları kabul ettim dedikten sonra kendisi "Elhamdü lillâhi Rabbill-âlemîn" derdi. Ardından makası alıp tekbir getirdikten sonra saçından sağ taraftan birkaç tüy daha sonra sol taraftan da birkaç tüy keserdi. Yine tekbir getirip dört dilimli külahı mürîdin başına koyardı. Ardından mürîde iki rekât nafile namaz kıldırır daha sonra beş vakit namaz, Cuma guslü ve Cuma namazına dikkat etmesini tembihlerdi. Ardından şunları tavsiye ederdi: "Akşam namazından sonra dört rekât nafile namaz kıl, her rekâtta Fatiha'dan sonra üç defa İhlas oku, sonra imanın selameti için iki rekât namaz kıl, her rekâtta Fatiha'dan sonra yedi defa İhlas bir Felak bir Nas oku, selam verdikten sonra "ya Hay ya Kayyûm sebbitni ale'l iman" duasını üç defa oku, yatsı namazından sonra iki rekât nafile kıl her rekâtta Fatiha'dan sonra on defa İhlas oku, selamdan sonra yetmiş defa "ya Vahhap" zikrini çek. Hicrî takvime göre her ayın 13, 14, 15'in de oruç tut" şeklinde bîat verdiği söylenir. ${ }^{70}$

\subsection{Mürîd- Mürşid}

Tasavvufî eğitim, büyük oranda mürîd ile mürşid arasındaki birlikteliğe dayanır. "Tıpkı Hz. Peygamber ile ashabı arasında olduğu gibi mürşid genel anlamda İslâm'ın özelde ise tasavvufun prensiplerini mürîdlerine örnek olmak suretiyle aktarır. Bu eğitim metodu tasavvufta sohbet olarak

69 İkbâlüddin, Tezkire-i Hâce Gîsûdırâz, 73-75.

${ }^{70}$ Gîsûdırâz, Şerh-i Cevâmi'u'l-Kelim, 92. 
adlandırılır. Mürşid, mürîdlerine bir taraftan sözlü olarak diğer taraftan da bizzat uygulamalı olarak temel ilke ve esasların hayata nasıl aktarılabileceğini göstermektedir. Bunun karşısında mürîd ise birtakım kurallara ve edeplere riayet etmekle yükümlüdür. Bunun için tasavvuf kaynaklarında mürşidde bulunması gereken nitelikler ve bunun yanında mürîdin şeyhine karşı riayet etmesi gereken edepler ayrıntılı şekilde ele alınmış, böylece sağlam bir mürîd- mürşid ilişkisinin temelleri atılmıştır."

Gîsûdırâz, tasavvuf yoluna giren mürîdin öncelikle farzları yerine getirmesi gerektiğini ardından şeyhin emirleri doğrultusunda hareket etmesi icap ettiğini belirtir. Ona göre sebepsiz yere Allah'in hükümleri terk edilemeyeceği gibi şeyhin dedikleri de terk edilmemelidir. Gîsûdırâz, her ne kadar Yüce Allah'ın peygamber vasıtası olmadan mahlukatı hidayet etme kudreti varsa da ancak sünnetullah gereği her kavmin hidayeti için bir peygamber gönderdiğini ifade eder. Aynı şekilde mürşidlerin de insanları bu şekilde Hakk'a davet ettiklerini bu yüzden mürîdin bu yolda mesafe alabilmesi için mürşidinin sözlerine bağlı kalması gerektiğini belirtir. Bir pîre intisab eden kendi benliğini terk etmesi gerektiğini eğer pîrin dedikleri doğrultusunda hareket etmezse ister havada uçsun ister su üzerinde yürüsün, ya da arkasını görebilsin bunun bir hiç hükmünde olduğuna dikkat çeker. Bu yolda ilerlemek isteyen mürîdin mürşid edinmesi gerektiğini aksi halde Hakk Teâlâ'ya ulaşmasının zor olduğunu ifade eder. $^{72}$

Gîsûdırâz, tasavvuf yoluna ayak basan mürîdin aşağıdaki şartlara riayet etmesini gerekli görür:

a) Öncelikle bu yola girmek isteyen talib ilk şart olarak gerçek bir mürşid arayışına girmelidir.

b) Kalben dünyadan ilişkisini koparmalıdır.

c) Halvet ve uzleti tercih etmelidir.

d) Avret yerlerini korumalıdır.

e) Helal gıda tüketmeye hassasiyet göstermelidir.

f) Mürşidinin emirlerine uymada gayret göstermelidir.

g) Az uyumalıdır.

h) Nefsine muhalefet etmelidir.

i) Ecdadının ilim ve faziletiyle övünmemelidir.

j) İlmî münazaralardan kaçınmalıdır. ${ }^{73}$

Zâhirî hastalıkların tedavisinde uzman bir doktora başvurulması ge-

${ }^{71}$ Mahmud Esad Erkaya, "Hâlidiyye Tasavvuf Geleneğinde Mürid- Mürşid ílişkileri”, e-Şarkiyat İlmi Araştırmalar Dergisi 9/2 (2017), 839.

72 Gîsûdırâz, Şerh-i Cevâmi'u'l-Kelim, 92.

${ }^{73}$ Hüseyin, Sîret-i Pâk Hazret-i Seyyid Muhammed Gîsûdırâz, 109. 
rektiği gibi bâtinî hastalıkların tedavisinde de hakiki bir mürşide başvurulması gerekir. Gîsûdırâz, mürşidin gönül hastalıklarının tabibi olduğunu bu yüzden kendisine mürîd olmak için gelenlerin mânevî hastalıklarını bilmesi gerektiğini aksi takdirde ona mürşid denilemeyeceğini ifade eder. Çünkü bir mürşidin birine hırka giydirmesi demek, mürîdin istikamet ehli ve bu yolda samimi olduğu anlamina gelir. Aksi halde eğer mürşid hastanın hastalığını bilmiyorsa o zaman hastalığı tedavi edemeyecek ve bu yüzden ona mürşid denilmeyeceğini vurgular. ${ }^{74}$

\section{Sonuç}

Hind Müslümanları arasında dinî anlayış, ehl-i sünnetin tasavvuf çizgisinde gelişmiştir. Gîsûdırâz kendi zamanında bu çizginin devamına katkı sağlamıştır. Çiştiyye tarîkatına mensup olan Gîsûdırâz, çok yönlü bir sûfî olup farklı dillere hâkimdir. Kendine hâs bir meşrebe sahip olan Gîsûdırâz, şerîatın zâhirine ters gördüğü sûfîlerin görüşlerini, tenkit etmekten geri durmamıştır. Eserlerinde, birbirini tamamlayıcı olarak gördüğü şerîatla tarîkat arasında köprü kurma arzusu tespit edilmiştir. Zira onun nezdinde şeriatla tarîkat farklı isimlerle anılsalar bile aslında birdir. Sûfî olmanın yanı sıra alim olan Gîsûdırâz, tasavvuf yoluna ilimsiz girenlerin vesveselere yenik düşerek işin sonunda mecnun veya dinden çıkma tehlikesiyle karşı karşıya kalacaklarını belirtmiştir. Nazarî tasavvufla ilgili önemli sayıda eser telif eden Gîsûdırâz, velâyet makamını marifetullah ve Yüce Allah'ın katındaki hakikatlere muttalî olmak şeklinde tarif etmekle birlikte velâyetin hiçbir zaman nübüvvetten üstün olmadığını, aksine velâyetin son derecesinin nübüvvetin ilk derecesine denk düştügünü ifade etmiştir.

Gîsûdırâz, etkilenme konusunda kulağın gözden daha etkili olduğunu iddia ederek kişinin âşıkların sözlerine kulak vermekle gönlünde ilâhî aşkın daha hızlı bir şekilde gelişeceğini belirtmiştir. Bu yüzden kişinin ilâhî aşkı elde edebilmesi için aşk ehli zatların sohbetinde bulunması gerektiğini ifade etmiştir. Kerameti muhalı ispat etmek değil de adet dışı şeylerden ibaret gören Gîsûdırâz, peygamberlerin mûcizeleri gibi evliyânın kerâmetlerinin de hak olduğunu belirtmiştir. Fakat tasavvuf ehli nezdinde mûcizelerin izhârı esâs iken kerâmetlerin gizli kalmasının temel prensip olduğunu ifade etmiştir. Ancak gaybî işaret veya İslâm'ı tebliğ etmek amacı ile kerâmeti izhar etmede herhangi bir problem olmadığını söylemiştir. Gîsûdırâz, nefsin farklı mertebeleri olsa da aslında nefsin bir tane olduğunu ve bunun da temelinde kötülüğü emreden nefs-i emmâre ol-

${ }^{74}$ Hüseyin, Sîret-i Pâk Hazret-i Seyyid Muhammed Gîsûdırâz, 109. 
duğunu belirtmiştir. Ancak peygamberlerin nefislerini bunun dışında tutarak onların nefislerinin mutmainne kısmında olduğunu savunmuştur. Gîsûdırâz, semâ'ı kabul etmekle birlikte fakat mürîdlerin semâ ettikleri sırada oyun havasında yapmalarını tasvip etmemiş ve bu tür şeylerin hiçbir hakikatinin olmadığını bunların beyhûde hareketler olduğunu ifade etmiştir. Gîsûdırâz, müridin tasavvuf yolunda ilerleyebilmesi için mürşidinin gözetiminde cehd içinde olmasının gereğini belirtmiştir. Ayrıca mürîdin mürşitten istifade edebilmesi için gönülden şeyhine bağlı olması gerektiğinin altını çizmiştir. Son olarak Gîsûdırâz'ın ilk dönem Çiştiyye tarîkatı içerisinde eser telifine yoğunlaşan bir şahsiyet olarak karşımıza çıktığını ifade edebiliriz. Ayrıca diğer Çiştiyye pîrleri vahdet-i vücûdu savundukları halde kendisi buna karşı çıkmış ve vahdet-i şühûdu savunmuştur.

\section{Kaynakça}

Akdağ, Eyyup. “Hallâc'ın Mahkeme Süreci ve Katline Fetvâ Verenler". Dinbilimleri Akademik Araştırma Dergisi 20/2 (2020), 1167-1194.

Âryâ, Ğulâm Ali. Tarîkati Çiştiyye der Hind-u Pakistan. İran: Zevâr Yayınları, 1964. Cebecioğlu, Ethem. Tasavvuf Terimleri ve Deyimleri Sözlüğü. İstanbul: Anka Yayınları, 2005.

Çelik, İsa- Tay, Ömer. "Çiştiyye Tarîkatının Semâ ve Mûsikîye Yaklaşımı”. Çukurova Üniversitesi Ilahiyat Fakültesi Dergisi (ÇÜIFD) 21/1 (22 Haziran 2021), 210-230.

Çetin, Nuran. "Müştâk Baba ve Kuddûsî Baba Dîvânlarında ilâhhî Aşk Anlayışı Üzerine Değerlendirme”. Hitit Üniversitesi İlahiyat Fakültesi Dergisi 18/35 (2019), 233-258.

Çift, Salih. “Tasavvufta Velâyet Kavramı: Hakîm Tirmîzî Örneği”. Bursa' da Dünden Bugüne Tasavvuf Kültürü - 2. İstanbul: Graphis Matbaa, 2003.

Çiştî Nizâmî, Hüseyin. Siret-i Tayyibe Hazret-i Muîü̈ddîn-i Çiştî. Lahor: Ekber Beg Yayınları, 2004.

Ensârî, Hâce Abdullah el-. Menâzilü’s-sâirîn. çev. Abdurrezzak Tek. Bursa: Emin Yayınları, 2017.

Erkaya, Mahmud Esad. "Hâlidiyye Tasavvuf Geleneğinde Mürid - Mürşid İlişkileri”. e-Şarkiyat ílmi Araştırmalar Dergisi 9/2 (2017), 839-861.

Erkaya, Mahmud Esad. "III. Uluslararas1 el- Farabi Sosyal Bilimler Kongresi”. 355363. Ankara: İksada Yayınları, 2018.

Feşâreki, Mühsin Muhammedî- Şîrânî, Meryem. “Tetebbü-i der Şerhi Gîsûdırâz ez ber Risâle-i Kuşeyriyye”. Neşriyye-i îlmî 1/32 (1396), 67-90.

Gîsûdırâz, Ebü'l-Feth Sadrüddîn Seyyid Muhammed b. Yûsuf el-Hüseynî. Enîsü'l'Uş̧̧âk. Haydarâbâd, 1360. 
Gîsûdırâz, Ebü'l-Feth Sadrüddîn Seyyid Muhammed b. Yûsuf el-Hüseynî. Esmârü'lEsrâr. Haydarâbâd, 1350.

Gîsûdırâz, Ebü'l-Feth Sadrüddîn Seyyid Muhammedb. Yûsuf el-Hüseynî. Mecmû́a-i Yâzde Resẩil (Risâle-i İstikâmeti Şeriat bı Tarîk-i Hakikat). Haydarâbâd, 1941.

Gîsûdırâz, Ebü'l-Feth Sadrüddîn Seyyid Muhammed b. Yûsuf el-Hüseynî. Mektûbât-i Gîsûdırâz. Haydarâbâd, 1362.

Gîsûdırâz, Ebü'l-Feth Sadrüddîn Seyyid Muhammed b. Yûsuf el-Hüseynî. Şerh-i Cevâmi'u'l-Kelim. Lahor: el-Faysal, 2010.

Gîsûdırâz, Ebü'l-Feth Sadrüddîn Seyyid Muhammed b. Yûsuf el-Hüseynî. Terceme-i Âdâbü'l-mürîdîn. Haydarâbâd, 1358.

Hüseyin, Şebîr. Sîret-i Pâk Hazret-i Seyyid Muhammed Gîsûdırâz. Lahor: Urdubâzâr, 2002.

İkbâlüddin, Ahmed. Tezkire-i Hâce Gîsûdırâz. Haydarâbâd, 1966.

Kerbelâ-1̂, Mürtezâ- Nâcî, Hâmid. "Seyyid Muhammed Gîsûdırâz'u-Nakdi Nazariye-i Vahdet-i Vücûd-i İbnü'l-Arâbî”. Pejveheşnâme-i Mezâhib-i İslâm 5 (2017), 49-67.

Konukçu, Enver. "Behmenîler”. Türkiye Diyanet Vakfi İslam Ansiklopedisi. 5/353-354. İstanbul: TDV Yayınları, 1992.

Kuşeyrî, Abdulkerim b. Havâzin. Kuşeyrî Risâlesi. İstanbul: Semerkand, 2019.

Kuşeyrî, Abdulkerim b. Havâzin. Kuşeyri Risalesi, ts.

Mevdûdî, Ahmed şâh Çiş̧î. Târih-i Çişt û Meşâyih-i Çiştiyye. Herât: İntişârât-i Ahrârî, 1976.

Mîrhord, Muhammed b. Mübârek b. Muhammed Alevî Kirmânî. Siyerü'l-Evliyâ. Lahor: Müştâk Ahmed Yayınları, 1885.

Muhaddis ed-Dihlevî, Abdülhak. Ahbârü'l-AhyârfiEsrâri'l-Ebrâr.Tahran: Encümen-i Âsâru Mefâhir-i Ferhengî, 1963.

Nedvî, Ebu'l Hasan Ali en-. İslâm Önderleri Tarihi. çev. Yusuf Karaca. İstanbul: Kayıhan Yayınları, 1992.

Nizâmî, Halik Ahmed. “'Gîsûdırâz’. Türkiye Diyanet Vakfi İslam Ansiklopedisi. 14/9495. İstanbul: TDV Yayınları 1996.

Popovic, Alexandre- Gilles, Veinstein. İslâm Dünyasında Tarîkatlar. çev. Osman Türer. İstanbul: Sûfî Yayınları, 2004.

Sayın, Esma. "Tasavvufî Kavramlarla Anlamsal Bağları Açısından Kerâmet Kavrami”. Bahkesir İlahiyat Dergisi 12 (2020), 239-251.

Selvi, Dilaver. "Biat Sünnetnin Tasavvufta İhyası". İhya Uluslararası İslam Araştırmaları Dergisi 1/1 (2015), 1-28.

Siyâlvî, Ahmed Fârûkî. Tezkire-i Evliyâa-i Çişt. Lahor: Sadr Bâzâr, ts.

Tan, Nedim- Kırmızı, Nazire. “Abdülkâdir Geylânî ve İbnü'l-Arabî’ye Nispet Edilen Bir Metin: Gavsiyye Risâlesi Hakkında Bir Literatür Değerlendirmesi”. Kocaeli Üniversitesi İlahiyat Fakültesi Dergisi 1/1 (2017), 19-39. 
Tay, Ömer. "Hindistanlı Bir Sûfî: Nasırüddîn Mahmûd b. Yahyâ Çırâğ-1 Dehlî ve Tasavvuf Anlayışı”. Sakarya Üniversitesi İlahiyat Fakültesi Dergisi 23/43 (15 Haziran 2021), 191-215. https://doi.org/10.17335/sakaifd.872145

Tay, Ömer. Muînüddîn-i Çiştî ve Çiştiyye Tarîkatı. Erzurum: Atatürk Üniversitesi, Doktora, 2021.

Uludağ, Süleyman. "Nefis”. Türkiye Diyanet Vakfi İslam Ansiklopedisi. 32/526-529. İstanbul: TDV Yayınları, 2006.

Uludağ, Süleyman. Tasavvuf Terimleri Sözlüğüu. İstanbul: Kabalcı Yayınları, 2005.

Vâizî, Abdülazîz b. Şîr Melik. Târîh-i Habîbî ve Tezkire-i Mürşidî. Haydarâbâd, 2005. 